\title{
Relative and Conditional Clause Constructions in İyàgà Dialect
}

\author{
Oluwole Samuel Akintoye \\ Ekiti State University
}

\begin{abstract}
Correspondence concerning this article should be addressed to Akintoye Oluwole Samuel, Department of Linguistics and Nigerian Languages, Faculty of Arts, Ekiti State University, Iworoko road, Ado Ekiti, Ekiti State, Nigeria, 360213. E-mail: akinwolesam1@gmail.com
\end{abstract}

\begin{abstract}
Relative Clause has been discussed as a subordinate clause used to qualify a noun. It narrows down the meaning of the noun it qualifies. A relative clause marker tí is inserted to accomplish the noun qualified having coded in the sentence initially in Yoruba language on the one hand. On the other hand, a conditional clause in Yoruba language is introduced with tí-clause by coding it in the sentence initially as well. The paper focuses on relative clause and conditional clause constructions in the İyàgbà dialect of Yoruba; a regional dialect in the north-east Yoruba. The author observes that though there are many scholarly works on the relative and conditional clause constructions in the Yoruba language, attention has not been paid to the relative and conditional clause constructions in the dialects of Yoruba. The data were collected from the informants from these dialect communities who reside in these communities and speak the dialects fluently, and the literature materials on these topics. The data presentation shall be based on descriptive analysis. Findings reveal that relative clause markers in the İyàgbà dialect are in complementary distribution; they occur in an exclusive environment. Apart from that, conditional clause markers are not attested in the dialect
\end{abstract}

Keywords: relative clause, standard Yoruba, dialects, scholars, conditional clause

Relative Clause Construction in both standard Yoruba and its dialects has attracted the attention of Yoruba scholars. Bamgbose $(1967 ; 1975 a ; 1975 b ; 1990)$ and Awobuluyi $(1975 ; 1978)$ independently explain that a relative clause is derived from a simple sentence and it is used to qualify a noun. These two scholars accept that a relative clause is introduced by a $\boldsymbol{t} i$-clause which appears immediately after the relativized items as shown below.

Omo tí ekùn bí

Child REL tiger bear

The child that tiger gave birth to

The status of tí-clause has generated significant arguments among Yoruba scholars. For instance, Bamgbose (1975, pp. 1-16) is of the opinion that not all the clauses introduced by tí-clause are relative clauses. Hence, it is not sufficient to use the presence of tí- clause as evidence of a structure being a relative clause. He claims that while it is true that a tí-clause can introduce a relative clause, it as well introduces nominalization having a factive and a manner meaning.
Lílú tí Olú ń lu ìlù

The fact that Olu beat the drum

The manner at which Olu beat the drum

A tí-clause introduces a relative clause when it appears after relativized NPs and also nominalization having a factive and a manner meaning when it occurs after nominalized verbs.

Awobuluyi (1975, pp. 1-11) has a contrary opinion. While Bamgbose argues that tí-clause only introduces a relative clause when it occurs after a true noun and nominalization when it occurs after a nominalized verb. According to Awobuluyi (1975, pp. 1-11), tíclause always introduces a relative clause construction when it appears after the relativized items whether the relativzed item is a noun or a nominalized verb and it conveys a relative clause meaning. Akintoye (2015, pp. 40-45) is of the opinion that tí-clause performs dual functions; it functions as both a relative marker and a conditional clause marker. It introduces a relative clause when it occurs after the relativized items and a conditional clause when it appears at the initial position of a conditional sentence. 
The focus of this paper is to examine relative and conditional clause constructions in the İyàgbà dialect and compare them with how the two clauses operate in other dialects of Yoruba. This research work will be a contribution to the existing works on the syntax of Yoruba dialects. The data presentation for this paper shall be based on descriptive analysis. This will enable the author to have a comprehensive explanation on the operation of relative and conditional clause constructions in the dialect under discussion. The data were collected from the native speakers of Iyàgbà dialect. They reside in the dialect communities and they are fluent in speaking the dialect. Some of the informants are farmers and illiterates. They do not see any value in researching their dialect. Therefore, they did not give the author enough information. Because the author is not a member of the dialect community, some of the informants were suspicious and very careful in their response to the author's interview. The author also makes use of texts and articles in journals on relative and conditional clause constructions in the standard Yoruba and its dialects.

The paper is divided into three parts. Part one is the introduction. Part two contains the conditional clause construction in İyagbà dialect. The focus of part three is the relative clause construction in Iyàgbà dialect.

\section{Materials and Methods}

\section{Conditional Clause in İyàgbà Dialect}

İyagbà dialect is one of the regional dialects spoken in the Northeast Yoruba according to Oyelaran (1977) and Awobuluyi (1998). İyàgbà speakers occupy the Northeast of Kogi-State and comprise three Local Government Areas. They are; İyagbà West with the headquarters at İgbárukù, İyàgbà East with the headquarters at İsánlu and Mọpàmùró Local Government with the headquarters at Mọpà. Each Local Government Area has many dialect communities under it which may not be possible to cover in a work like this. Therefore, the discussion and analysis shall be based on the sub-dialect of Mòpà. It is a good representative of other sub-dialects because all the sub-dialects of İyàgbà are mutually intelligible.

Like the standard Yoruba and its dialects, Conditional Clauses are attested in İyàgbà dialect of Yoruba. According to Kirkpatrick (2007, p. 52), a conditional clause is an adverbial clause that indicates a possible situation and its consequence. What Kirkpatrick's definition implies is that there are two events in a conditional clause in which one event gives rise to the other. This claim is similar to the claim in Awobuluyi (2013, pp. 254-294) who views a conditional clause as two events in which one occurs before the other and the second event modifies the first one.
Awobuluyi (1978, pp. 111-135) had earlier defined a conditional clause as a sentential modifier, modifying another sentence. Bamgbose (1967, p. 28; 1990, p. $197)$ views the conditional clause as an event that has never occurred. Both Awobuluyi (1978, pp. 111-135) and Bamgbose (1990, p. 97) are of the opinion that a conditional clause in Yoruba language is marked with the introducers bí and tí and the adverb bá as shown below.

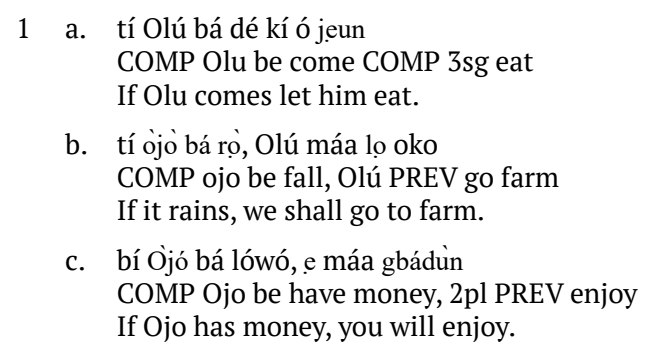

A look at the examples above shows that conditional clause markers tí and bi occupy the sentence initial position while the preverb bá 'be' preposes the verb dé 'come', rọ 'rain' and ní 'have' respectively. Conditional clauses are transposable in the standard Yoruba. That is, the two structures that form a conditional sentence can be displaced such that the conditional markers will appear in the middle position as demonstrated below

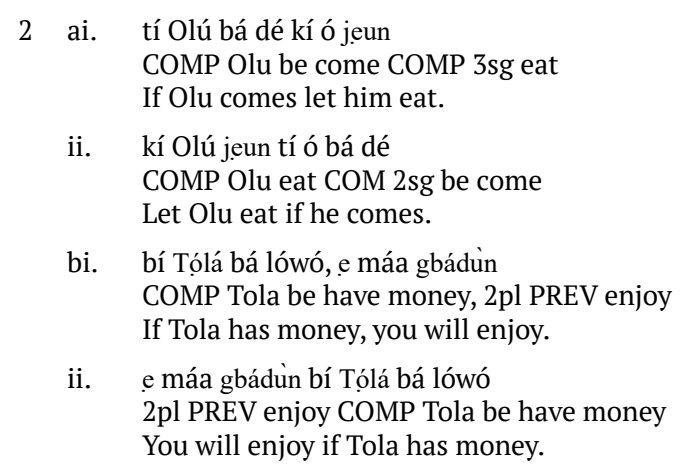

In examples (aii and bii) the subordinate conditional clauses tí ó bá dé 'if he comes' and bí Tọ́lá bá lówó 'if Tola has money' occupy the middle position respectively.

Like the standard Yoruba, conditional sentences are present in the dialects of Yoruba. For instance, although the conditional clause markers appear at the sentence initial position, they vary form one dialect to the other. For instance, Ondó dialect employs di while Èkitì dialect employs kí to mention a few as demonstrated below.

3. Ondó dialect

Di Olú bá wa, á ka jẹn

COMP Olu be come PREVs eat

If Olu comes, he will eat

Di iba i bá nówó e ka gbádùn

COMP father be have money 2sg PREVs enjoy

If father is rich, you will enjoy. 
4. Òmùo dialect

a. Ki Olú bá á, aá jẹun COMP Olu be come PREV eat If Olu comes, he will eat.

b. Ki bàbá bá léó, è ka gbádùn COMP father be have money 2sg PREV enjoy If father is rich, you will enjoy.

Examples $3(a, b)$ and $3(a, b)$ above indicate that as it is found in the standard Yoruba, the preverb bá 'be' also accomplishes the function of a conditional clause marker in the dialects of Yoruba.

A question we should ask is whether the presence of conditional clause markers and the preverb bá in the conditional sentence are enough to identify a conditional construction in the standard Yoruba and its dialects. The reason both conditional markers and bá can sometimes be deleted in the construction without altering meaning as shown below.

\section{Standard Yoruba}

a. Bí o bá fẹ́ bí o bá kọ̀, ó maá tẹlé e COMP 2sg be like COMP 2sg be refuse 3sgPREV follow you Whether you like it or not, he will follow you

b. Bí o fé bí o kọ, ó màa tẹ̀lé é COMP 2sg like COMP 2sg refuse, 3sgPREV follow you Whether you like it or not, he will follow you

c. O fé o kọo, ó maá tẹ̀lé e 2 sg like 2 sg refuse, 3 sg PREV follow you Whether you like it or not, he will follow you.

6a. Bí ojò bá rọ bí ojò kò bá rọ̀, ịu á ta COMP rain be fall COMP rain NEG be fall, yam PREV germinate.

Whether it rains or not, the yam will germinate

b. Bí ojó rọ bí ojò kò rọ, isu á ta COMP rain fall COMP rain NEG fall, yam PREV germinate Whether it rains or not, yam will germinate

c. Òjó rọ, ojò kò rọ, isu á ta Rain fall, rain NEG fall, yam PREV germinate Whether it rains or not, yam will germinate

There are some dialects of Yoruba, especially the regional dialect under study, where a conditional clause marker is not attested. For instance, unlike the standard Yoruba and some other dialects of Yoruba where conditional clause markers are attested as demonstrated in examples (2), (3) and (4) above, a conditional clause marker is not obtainable in the İyàgbà dialect as shown below.

\footnotetext{
7. Mọpà dialect

a. Olú bá rè, ghọn á ghá

Olu be go, 3plPREV come

If Olu goes, they will come

b. Ghọn bá jẹun alé tán, e gha retí gha $3 \mathrm{pl}$ be eat night finish, $2 \mathrm{pl}$ PREV expect $1 \mathrm{pl}$ If they finish lunch, be expecting us.

c. Olu bá máà jìyà, ẹ ra rè

Olu be NEG punish, NEG go

If Olu is not discipline, he will not go.
}

In examples 6 (b) and 7 (b) above, the preverb bá 'be' is deleted and in examples 4 (c) and 6 (c), both the conditional clause marker and the preverb bá are deleted. Whereas, a conditional clause marker is absent in the examples (7) above, but the preverb bá 'be' which always occurs with the conditional clause marker in the standard Yoruba and in some dialects of Yoruba is present. Even when the two conditional structures are transposed, the conditional marker is still absent as demonstrated below.

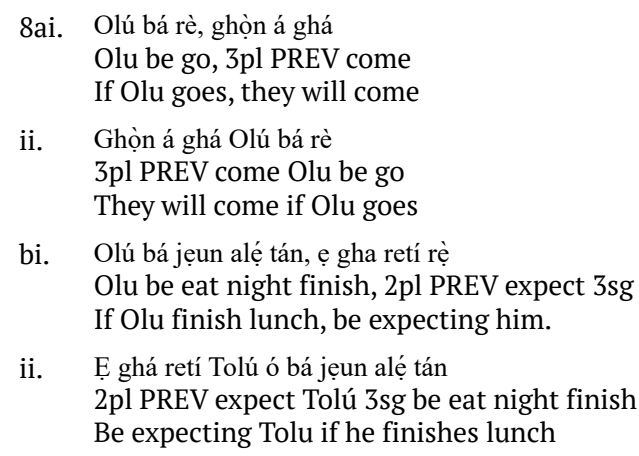

It is evident, according to the examples (8) above that conditional marker is not observable in the İyàgbà dialect. One can now say that the occurrence of both the conditional clause marker and the preverb bá is obligatory in both standard Yoruba and its dialects on the one hand. On the other hand, the realization of a conditional sentence depends on the discretion of the native speaker At times, if one compares the occurrence of the conditional markers and bá with the occurrence of the relative clause tí and the focus clause ni in the sentence, it may be evident that these two markers are also obligatorily deleted as demonstrated below.

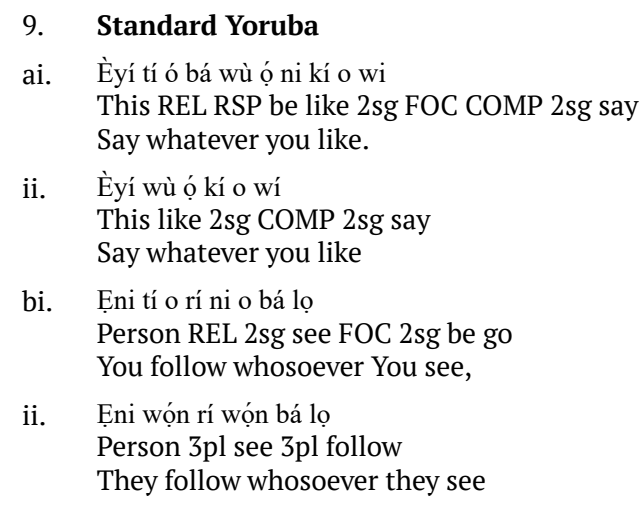

In examples 7 (aii) and 9 (bii) above, both relative and focus markers are deleted without altering the meaning of the expressions. This shows that in the standard Yoruba and its dialects, the occurrence of relative, focus and conditional markers is obligatory as earlier noted and their realization depends on the discretion of interlocutors.

In addition to this, bí and bá can also appear in expressions without giving conditional clause 
meaning as shown below.
10. Standard Yoruba
ai. Olu bá gba kámú ní tirè̀ nigba tí ó sún un
Olu be accept fate PART his when RSP feed up 3sg Olu then accept fate when he was fed up.
ii. Olú bá jókòó rẹ̀ jéẹjẹeé nígbà tí kò mọ èyí tí ì bá șe Olu be sit his gently when NEG know this REL PREV be do Olu then sat down gently when he did not know what he could do
iii. Ò bá kúkú gbà fún Ọọọun ní órí ọ̣ọ̀ yií 2sg be ADV accept PREP God PREP head word this You had better accept for God on this matter.
bi. Bí wọ́n șe jí owó náà kò yé e Be 3pl do steal money DET NEG understand 3sg He did not understand the way they stole the money
ii. Bí Olú șe gbọ ọ̣ọ̀ náà ni ó bú sẹ́kún Be Olu do hear word DET FOC 3sg burst to tear As Olu heard the matter, he was crying

In examples 10 (i-iii) and 9 (i, ii), both bá and bí function as adverbs. If one compares the examples above with examples in (7), one can easily say that bá in the conditional sentence in the İyàgbà dialect cannot be an introducer of a conditional sentence. A critical look at these examples shows that in both examples 6 and 8 (ai-iii), the preverb bá 'be' preposes verbs. What we are trying to put forward is that if bá 'be' performs the same function in examples 7 and 9 (i-iii) above, it cannot be said that bá is a recoverability of the conditional clause marker in the İyàgbà dialect unless there is evidence that bá performs dual function. The observation is that although the İyàgbà dialect does not have a conditional clause marker, a conditional sentence is realized by discretion of the native speaker.

\section{Results and Discussion}

\section{Relative Clause Construction in the İyàgbà Dialect}

Scholars like Awobuluyi (1978, pp. 35-37) and Bamgbose (1990, p. 123) have explained that a relative clause construction is derived by movement transformation. A simple sentence is reduced to a relative clause by moving the relativized items outside the higher clause to the initial position of the relative clause construction. According to Hastings (2004, pp. 54-60), Mureili (2008, pp. 1-4) and Andreea (2010, p. 7), a relative clause is an attribute which qualifies the head of the noun phrase. It narrows down the potential reference of an NP by specifying the role of the reference of that NP.

Following the definition of the scholars above, a relative clause is a subordinate clause that qualifies and narrows down the meaning of a noun. Although Kayne (1994), Borsly (1997, p. 629) and Bianchi (2000, p. 145) mention the different types of relative clauses; Restrictive, Unrestrictive and Free or Zero relative clauses, in this paper, we shall limit our discussion to the restrictive relative clause. The reason is that the restrictive relative clause is more prominent in the standard Yoruba and its dialects.

The structures of a relative clause construction in both the standard Yoruba and its dialects are identical in the sense that there is movement transformation as earlier noted and the relative marker comes after the relativized items. The only difference is that a relative marker manifests itself in different forms in the dialects of Yoruba. For instance, it takes tí form in the standard Yoruba and in some Northwest Yoruba such as İbàdàn, Òșogbo, Șakî and İgbòho to mention a few. A relative marker takes two forms; ghin and $\mathbf{n}$ in the İyàgbà dialect as demonstrated below.

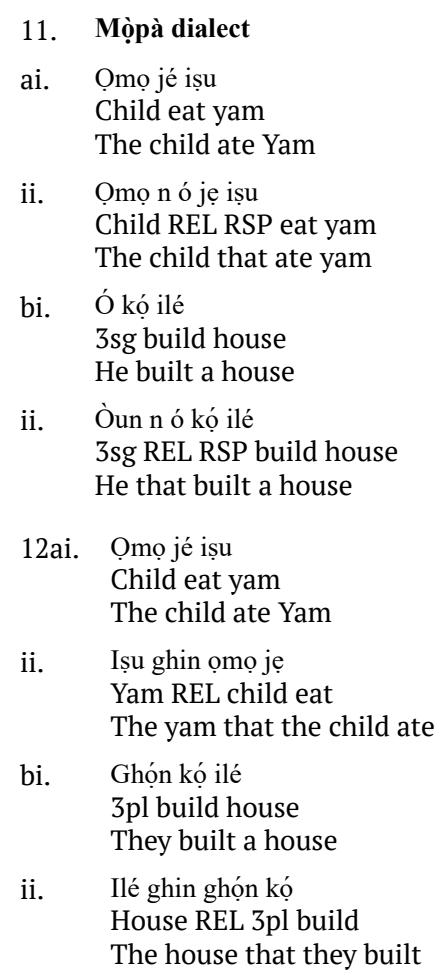

In examples 11 (aii), 11 (bii) above, the relative clause marker $\mathbf{n}$ co-occurs with ó whereas the relative clause marker ghin co-occurs with omo 'child', the 3sg ghọn 'they' in examples 12 (aii), 12 (bii). This indicates that each of the relative clause markers $\mathbf{n}$ and ghin is restricted to a particular domain; $\mathbf{n}$ occurs with a resumptive pronoun whereas ghin occurs with NPs. If one considers the Ìkàlè dialect, there is a tendency for one to view $\mathbf{n}$ as the proform of the relativized items or a reduced form of òn as manifested below.

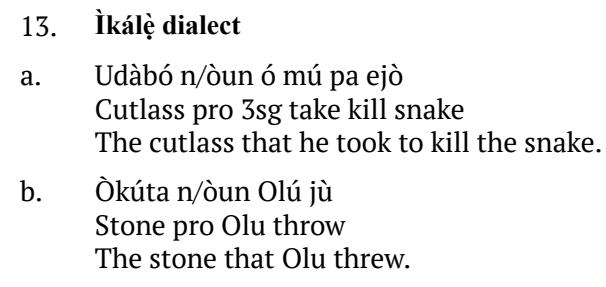


A critical look at the examples above shows that $\mathbf{n}$ / òu are allomorphs and they refer to the relativized NPs; udàbó 'cutlass' and òkúta 'stone' respectively. This type of proform is common in Yoruba literature as demonstrated below.

12a. A-ṣápẹ-fún-wèrè-jó òun pẹlú wèrè ẹgbẹra ni

A person that beats bell for a mad man to dance, he and the mad are equal.

b. A-lù-fún-wèrè-jó òun wèrè jọ lộkanùn kanùn

A person that beats drum for a man to dance, he and the mad man are the same thing

(Olatubosun, 1973, p. 83)

In the examples above, the $3 \mathrm{sg}$ òun 'he' is referring to the subject NPs A-șápẹ́-fún-wèrè-jó 'he that beats bell for a mad man' and A-lù-fún-wèrè-jó 'he that beats drum for a mad man'. But if one considers the example below, one may argue that $\mathbf{n}$ cannot be the reduced form of òn because if it is so, òun and $\mathbf{n}$ could not have co-occurred.

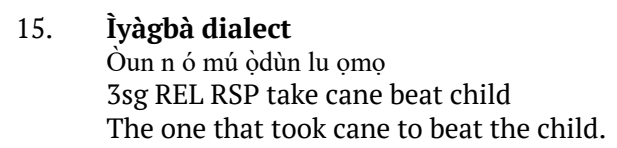

\section{Conclusion}

Conditional and relative clause constructions in the dialect of İyàgbà, a regional dialect in Northeast Yoruba, have been examined. Unlike the standard Yoruba and some dialects of Yoruba, a conditional clause marker is not attested in the İyàgbà dialect. The author also argued in this paper that the presence of bá 'be' is not enough to determine a conditional clause construction in the İyàgbà dialect and that the realization of $\mathrm{a}$ conditional clause depends on the understanding of the native speakers through intonation. The author explained further that a relative clause marker takes two forms in the İyàgbà dialect; $\mathbf{n}$ and ghin, which occur in different domains. For instance, $\mathbf{n}$ co-occurs with a resumptive pronoun and ghin co-occurs with noun phrases. Further research on relative clause and conditional clause constructions will need to focus on comparative analysis of relative clause and conditional clause constructions in İyàgbà and the other dialects of Yoruba. This will enable the author to see if what is discussed in the paper is obtainable in other dialects of Yoruba.

\section{References}

Akintoye, O. S. (2015). A comparative analysis of relative and focus constructions in Ondo, Ekiti and
Iyagba dialects of Yoruba (Unpublished doctoral dissertation). Ekiti State University, Ado-Ekiti, Ekiti-State, Nigeria.

Andreea, S. C. (2010). Clefting and extraposition in English. ICAME Journal, 32, 7-37.

Arndt, R. (2009). Stress test for relative clauses. In A. Riester \& E. Onea (Eds.), Focus at the SyntaxSemantics Interface: Workshop paper of the SFB 732, 3 (pp. 69-85). Stuttgat, Germany: University of Stuttgat.

Awobuluyi, O. (1975). Relativization and nominalized sentences in Yoruba. Paper presented at the Department of Linguistics and African Languages, University of Ibadan, Ibadan, Nigeria.

Awobuluyi, O. (1978). Essentials of Yoruba grammar. Ibadan, Nigeria: Oxford University Press.

Awobuluyi, O. (2013). Ėkọ gírámà Ėdè Yorùba [Yoruba language grammar]. Òșogbo, Nigeria: Atman Limited.

Bamgbose, A. (1967). A short Yoruba grammar. Ibadan, Nigeria: Heinmann Educational Books Ltd.

Bamgbose, A. (1975a). Relative clause and nominalized sentences in Yoruba. Paper presented at the Linguistics and African Languages Department Seminar, University of Ibadan, Ibadan, Nigeria.

Bamgbose, A. (1975b). Relativization and nominalization? Case of structure versus meaning in Yoruba. Paper presented at the Linguistics and African Languages Department Seminar, University of Ibadan, Ibadan, Nigeria.

Bamgbose, A. (1990). Fonớlójì àti Gírámà Yorùba [Phonology and Yoruba grammar]. Ibadan, Nigeria: University Press PLC.

Bianchi, V. (2000). The raising analysis of relative clause: A reply to Borsly. Linguistic Inquiry, 31, 123140.

Borsly, R. D. (1997). Relative clauses and the theory of phrase structure. Linguistic Inquiry, 28(4), 629-647.

Hastings, R. (2004). The syntax and semantics of relativization and quantification: The case of Quechua (Unpublished doctoral dissertation), Cornell University, Cornell, NY.

Kayne, R. S. (1994). The antisymmetry of syntax. Cambridge, MA: Mass MIT Press.

Kirkpatrick, B. (2007). Correct English. Ghana: Scotland for EPP Book Service.

Mureili, A. (2008). Relative construction in European languages: A close look at non-standard varieties. MEL-Kompaktvoirlesung, 1, 1-3.

Olatubosun, O. (1973). Áròyé akéwì [Poor complaints]. Ibadan, Nigeria: Onibonoje Press and Book Limited.

Oyelaran, O. O. (1977). Linguistic speculations on Yoruba history. In Department of African Language and Literature Seminars. Ile-Ife, Nigeria: Obafemi Awolowo University. 